\title{
Nitrogen Fixation by Thiobacillus ferrooxidans
}

\author{
By MARY E. MACKINTOSH \\ Microbiological Research Establishment, Porton Down, Salisbury SP4 0JG
}

(Received 14 November 1977)

\begin{abstract}
Cultures of Thiobacillus ferrooxidans grown in the absence of a source of fixed nitrogen reduced acetylene to ethylene suggesting the presence of nitrogenase. This presumptive evidence has now been substantiated by the demonstration of the enrichment of ${ }^{15} \mathrm{~N}$ in the protein of the organism when grown under ${ }^{15} \mathrm{~N}_{2}$. The possibility that $T$. ferrooxidans was being grown in association with other nitrogen-fixing organisms was eliminated by the use of cultures derived from colonies whose development had been observed from single organisms.
\end{abstract}

\section{INTRODUCTION}

The acetylene reduction test is widely used to demonstrate the presence of nitrogenfixing enzyme systems in bacteria. It is based on the observation of Dilworth (1966) and Schöllhorn \& Burris (1967) that preparations of nitrogenase reduce acetylene specifically to ethylene. The iron-oxidizing bacterium Thiobacillus ferrooxidans reduces acetylene to ethylene (Mackintosh, 1971); this activity is repressed by growth in the presence of $\mathrm{NH}_{4}{ }^{+}$, which is good presumptive evidence for the presence of nitrogenase. Nitrogen fixation has not previously been demonstrated in this group of bacteria and therefore it is necessary to show that this organism does not just reduce acetylene per se but incorporates dinitrogen into cell material.

When $T$. ferrooxidans, whether isolated in a liquid culture or received from a culture collection, is plated out by the technique described in this paper at least two types of colonies are seen. One produces a brown precipitate of iron but the other does not; the latter may be T. acidophilus (Guay \& Silver, 1975). It has often been assumed that a liquid salts medium of acid $\mathrm{pH}$ containing $\mathrm{FeSO}_{4}$ as the source of energy is selective for $T$. ferrooxidans and that by subculture in such a medium a pure culture will be obtained. This is not so. Mixed cultures are still present after numerous subcultures in $\mathrm{FeSO}_{4}$ medium. Unless a strain is specifically purified and maintained under strict aseptic conditions it is highly probable that work is being carried out with a mixed culture. For this reason care was taken in the purification of the strain of $T$. ferrooxidans used for the nitrogen-fixation experiments.

\section{METHODS}

Bacterial strain. The strain of $T$. ferrooxidans was supplied by M. G. Yates (Unit of Nitrogen Fixation, University of Sussex). To eliminate the possibility of having a mixed or contaminated culture (Guay \& Silver, 1975; Tsuchiya, Trivedi \& Schuler, 1974), the strain used in this work was purified by a modification of the slide chamber technique (Postgate, Crumpton \& Hunter, 1961) which allowed the development of a bacterial colony from a single organism to be followed microscopically. A $5 \mathrm{~cm}$ Petri dish containing $2.5 \mathrm{ml}$ solid medium was placed in a metal holder which could be used on an ordinary microscope stage. Lugs on the holder were aligned with reference marks on the plate to ensure that the plate could be relocated precisely if movement occurred during incubation. The plates were inoculated with a dilute suspension of $T$. ferrooxidans and the positions of single organisms were identified by vernier scale readings. The plates, in their 
holders, were put inside larger Petri dishes containing damp filter paper to prevent desiccation of the medium. These were placed in a glass anaerobic jar under air $/ \mathrm{N}_{2} / \mathrm{CO}_{2}(1: 94: 5$, by vol. $)$ and incubated at $30^{\circ} \mathrm{C}$ for $36 \mathrm{~h}$. Colony growth of $T$. ferrooxidans was favoured by conditions of reduced oxygen tension (Mackintosh, unpublished observation). After incubation the plates were observed microscopically and the positions of microcolonies were noted. The plates were then re-incubated under the same conditions for $7 \mathrm{~d}$ during which time the microcolonies grew into visible colonies. A deep brown precipitate of ferric sulphate within and around the colony identified the organism as $T$. ferrooxidans. Organisms from one of these colonies were picked and inoculated into a flask of liquid medium and the culture was incubated at $30{ }^{\circ} \mathrm{C}$ for $5 \mathrm{~d}$. The whole procedure was repeated and the final strain was considered to be uncontaminated T. ferrooxidans.

Media. For the growth of the inoculum, a 'low phosphate' salts medium was used containing: $\left(\mathrm{NH}_{4}\right) \mathrm{SO}_{4}$, $1.0 \mathrm{mM} ; \mathrm{KH}_{2} \mathrm{PO}_{4}, 0.2 \mathrm{mM} ; \mathrm{MgCl}_{2}, 125 \mu_{\mathrm{M}} ; \mathrm{CaCl}_{2}, 1.0 \mathrm{mM} ; \mathrm{MnCl}_{2}, 0.5 \mu \mathrm{M} ; \mathrm{ZnCl}_{2}, 0.5 \mu_{\mathrm{M}} ; \mathrm{CoCl}_{2}, 0.5 \mu \mathrm{M}$; $\mathrm{H}_{3} \mathrm{BO}_{3}, 0.5 \mu \mathrm{M} ; \mathrm{Na}_{2} \mathrm{MoO}_{4}, 0.05 \mu \mathrm{M} ; \mathrm{CuCl}_{2}, 0.5 \mu \mathrm{M} ; \mathrm{H}_{2} \mathrm{SO}_{4}, 9.6 \mathrm{mM}, \mathrm{FeSO}_{4}, 180 \mathrm{~mm} ; \mathrm{pH} 1.8$ (D. Herbert, personal communication). This medium considerably reduced the amount of precipitate of basic iron sulphates formed during growth and also decreased the loss of bacteria which adsorb to this precipitate. The ${ }^{15} \mathrm{~N}_{2}$ incorporation experiments were carried out in a modified version of the medium devised by Leathen, Kinsel \& Braley (1956) $\left(\mathrm{F}_{2}\right.$ medium) which contained: $\mathrm{KCl}, 0.7 \mathrm{~mm} ; \mathrm{KH}_{2} \mathrm{PO}_{4}, 0.3 \mathrm{~mm} ; \mathrm{MgSO}_{4}, 2.0 \mathrm{~mm}$; $\mathrm{CaCl}_{2}, 0.06 \mathrm{~mm} ; \mathrm{Na}_{2} \mathrm{MoO}_{4}, 0.04 \mathrm{~mm} ; \mathrm{FeSO}_{4}, 180 \mathrm{~mm} ; \mathrm{pH} \mathrm{2.2}$. All media were sterilized by autoclaving at $103 \mathrm{kPa}$ for $15 \mathrm{~min}$ except for the ferrous sulphate which was filtered through a $0.45 \mu \mathrm{m}$ membrane filter (Millipore) and added aseptically. Thiobacillus ferrooxidans was maintained on $\mathrm{F}_{2}$ medium with added $1 \mathrm{~mm}-\left(\mathrm{NH}_{4}\right)_{2} \mathrm{SO}_{4}$, and purified on the same medium solidified with $0.8 \%(\mathrm{w} / \mathrm{v})$ agarose (BDH).

Gases. The ${ }^{15} \mathrm{~N}_{2}$ isotope was $99.4 \%$ pure (BOC). It was transferred from its container, which had been sealed with a Suba-seal closure (William Freeman \& Co, Staincross, Barnsley), to the culture vessel using a hypodermic syringe. The gas removed was replaced with an equal volume of sterile distilled water. Acetylene was made from calcium carbide and water (Postgate, 1972). Ethylene ( $99.9 \%$ pure) was obtained from BOC.

Preparation of the inoculum. A 1 litre culture of $T$. ferrooxidans was grown in $\mathrm{F}_{2}$ medium plus $\left(\mathrm{NH}_{4}\right)_{2} \mathrm{SO}_{4}$ at $30^{\circ} \mathrm{C}$ for $3 \mathrm{~d}$. This was used as the seed culture for a bottle containing 201 'low-phosphate' medium which was incubated at $30^{\circ} \mathrm{C}$ with forced aeration through a sintered glass sparger at 21 min $^{-1}$ for $48 \mathrm{~h}$. The culture was harvested by continuous flow centrifugation at $47000 \mathrm{~g}$ at $100 \mathrm{ml} \mathrm{min}{ }^{-1}$. The final yield of cells (about $0.5 \mathrm{~g}$ ) was resuspended in $20 \mathrm{ml} 5 \mathrm{~mm}-\mathrm{H}_{2} \mathrm{SO}_{4}$.

${ }^{15} \mathrm{~N}_{2}$ incorporation and acetylene reduction experiments. Experiments were carried out at room temperature $\left(22^{\circ} \mathrm{C}\right.$ ) in Bellco jars (A. R. Horwell, London), working volume $250 \mathrm{ml}$; these had a hanging bar magnet stirrer and two side-arms which could be loosely covered with screw caps, to prevent contamination but allow free passage of air, or hermetically sealed with Suba-seals. Jars and seals were sterilized by autoclaving at $103 \mathrm{kPa}$ for $15 \mathrm{~min}$. A series of seven jars were prepared each containing $210 \mathrm{ml} \mathrm{F}_{2}$ medium; subsequent treatments are detailed in Results.

Isotopic nitrogen ${ }^{15} N_{2}$ analysis. Analysis of the ${ }^{15} \mathrm{~N}$ in the concentrated samples was carried out by conventional Kjeldahl \& Markham distillation to recover $\mathrm{NH}_{4}{ }^{+} . \mathrm{N}_{2}$ was liberated from the samples by hypobromite oxidation and analysed in an AEI MS10 mass spectrometer.

Acetylene reduction test. Acetylene and its reduction product ethylene were determined by gas-liquid chromatography on a Pye model 104 chromatograph using a hydrogen flame ionization detector and a $152 \mathrm{~cm}$ glass column packed with Porapak R held at $65^{\circ} \mathrm{C}$. The carrier gas was nitrogen at a flow rate of $45 \mathrm{ml} \mathrm{min} \mathrm{m}^{-1}$. Gas samples $(1 \mathrm{ml})$, taken from the cultures which had received acetylene, were injected directly into the chromatograph through a gas sampling valve. Ethylene production was determined by comparing the areas of the peaks with those obtained with authentic ethylene diluted in $\mathbf{N}_{\mathbf{2}}$.

\section{RESULTS AND DISCUSSION}

Acetylene reduction tests (Mackintosh, 1971) indicated that the presumptive $\mathrm{N}_{2}$-fixing system in $T$. ferrooxidans was oxygen sensitive as discussed by Drozd \& Postgate (1970), and that highest activities were obtained with organisms in the exponential phase of growth. Thiobacillus ferrooxidans would be expected to require some oxygen for $\mathrm{N}_{2}$ fixation since the necessary metabolic energy must be generated from the oxidation of ferrous to ferric iron. It was therefore necessary to supply sufficient oxygen to allow enough iron oxidation to support measurable ${ }^{15} \mathrm{~N}_{2}$-fixation but insufficient to inhibit the expression of the nitrogenase system.

The natural abundance of ${ }^{15} \mathrm{~N}$ in dinitrogen and combined nitrogen is 0.366 atom $\%$. If incubation of cultures with ${ }^{15} \mathrm{~N}_{2}$ leads to an enrichment under the conditions of the exper- 


\section{Table 1. Incorporation of ${ }^{15} \mathrm{~N}_{2}$ into cell material by $T$. ferrooxidans under different conditions}

The various components $(10 \mathrm{ml}$ unless otherwise stated) were added to the jars at the times indicated. Each jar also received $150 \mathrm{~mm}_{-}-\mathrm{FeSO}_{4}$ at $18 \mathrm{~h}$ and $100 \mathrm{~mm}_{-}-\mathrm{FeSO}_{4}$ at $42 \mathrm{~h}$. Jars 1 and 2 were sealed at the start of the experiment, the other jars were sealed after $18 \mathrm{~h}$. After $96 \mathrm{~h}$, the extent of ${ }^{15} \mathrm{~N}_{2}$ incorporated was determined as described in Methods.

\begin{tabular}{|c|c|c|c|c|c|c|c|c|}
\hline & \multicolumn{7}{|c|}{ Jar number } \\
\hline & & 1 & 2 & 3 & 4 & 5 & 6 & 7 \\
\hline \multirow{3}{*}{ Times of addition } & $(0 \mathrm{~h}$ & ${ }^{15} \mathrm{~N}_{2}$ & ${ }^{15} \mathrm{~N}_{2}$ & - & -- & - & - & - \\
\hline & $18 \mathrm{~h}$ & $\begin{array}{l}{ }^{15} \mathrm{~N}_{2} \\
\text { air }\end{array}$ & ${ }^{15} \mathrm{~N}_{2}$ & ${ }^{15} \mathrm{~N}_{2}$ & ${ }^{15} \mathrm{~N}_{2}$ & ${ }^{14} \mathrm{~N}_{2}$ & $\begin{array}{c}{ }^{14} \mathrm{~N}_{2} \\
\mathrm{C}_{2} \mathrm{H}_{2}(2 \mathrm{ml})\end{array}$ & $\begin{array}{c}{ }^{14} \mathrm{~N}_{2} \\
\mathrm{C}_{2} \mathrm{H}_{2}(2 \mathrm{ml}) \\
\left(\mathrm{NH}_{4}\right)_{2} \mathrm{SO}_{4} \\
(1.0 \mathrm{mM})\end{array}$ \\
\hline & $42 \mathrm{~h}$ & air & - & ${ }^{15} \mathrm{~N}_{2}$ & ${ }^{15} \mathrm{~N}_{2}$ & ${ }^{14} \mathrm{~N}_{2}$ & ${ }^{14} \mathrm{~N}_{2}$ & ${ }^{14} \mathrm{~N}_{2}$ \\
\hline \multicolumn{2}{|c|}{$\begin{array}{l}{ }^{15} \mathrm{~N} \text { (atom \%) incorporated into } \\
\text { cell material }\end{array}$} & $\begin{array}{r}0.518 \\
\pm 0.015\end{array}$ & 0.369 & 0.479 & $\begin{array}{r}0.421 \\
\pm 0.007\end{array}$ & $0 \cdot 360$ & - & - \\
\hline \multicolumn{2}{|l|}{ Excess ${ }^{15} \mathrm{~N}\left(\right.$ atom $\left._{-}^{-} \%\right)$} & $0 \cdot 152$ & 0.003 & $0 \cdot 113$ & 0.055 & - & & \\
\hline
\end{tabular}

Table 2. Acetylene reduction by T. ferrooxidans

Jars were prepared and incubated as described in Table 1.

\begin{tabular}{ccc} 
& \multicolumn{2}{c}{ Ethylene produced $\left(\mathrm{nmol} \mathrm{ml}^{-1}\right.$ ) } \\
\cline { 2 - 3 } Time (h) & Jar 6 & $\begin{array}{c}\text { Jar } 7 \\
\text { (with } \mathrm{NH}_{4}{ }^{+} \text {) }\end{array}$ \\
0 & 0.024 & 0.031 \\
24 & 6.4 & 0.028 \\
48 & 80 & 0.030 \\
96 & 112 & 0.031
\end{tabular}

iment then fixation of dinitrogen must have occurred. Seven culture jars were prepared, four being used to test for ${ }^{15} \mathrm{~N}_{2}$ fixation (Table 1). The vessels were about $550 \mathrm{ml}$ total volume with $210 \mathrm{ml}$ medium and received a $1.5 \mathrm{ml}$ inoculum $(3.0 \mathrm{mg}$ dry. $w \mathrm{t})$. They were supplemented with $150 \mathrm{~mm}^{-F_{e S O}}$ after $18 \mathrm{~h}$ incubation and $100 \mathrm{~mm}_{4}-\mathrm{FeSO}_{4}$ after $42 \mathrm{~h}$. Two jars were sealed immediately and injected with $10 \mathrm{ml}{ }^{15} \mathrm{~N}_{2}$ (Table 1 , jars 1 and 2). Jar 1 received an additional $10 \mathrm{ml}$ of air after 18 and $42 \mathrm{~h}$; jar 2 did not. Significant ${ }^{15} \mathrm{~N}_{2}$ fixation occurred in jar 1 only, indicating that fixation probably occurred only under the microaerophilic conditions prevailing after the 18 and $42 \mathrm{~h}$ injections of additional air. Failure to observe fixation in jar 2 indicated that the oxygen concentration in air was inhibitory to $\mathrm{N}_{2}$ fixation in the initial stages of growth, as also shown by the failure to observe acetylene reduction during the early stages of growth (Table 2). Jars 3 and 4 (which represent separate experiments performed on two occasions) were sealed after $18 \mathrm{~h}$ and received $10 \mathrm{ml}{ }^{15} \mathrm{~N}_{2}$ at 18 and $42 \mathrm{~h}$. Both showed positive ${ }^{15} \mathrm{~N}_{2}$-fixation, consistent with microaerophilic conditions developing in the cultures because of rapid iron oxidation following sealing of the jars during exponential growth. The other three jars were also sealed after $18 \mathrm{~h}$. Jar 5 received no additions and was a control for the ${ }^{15} \mathrm{~N}_{2}$ analysis. Jars 6 and 7 were supplemented with acetylene for a standard acetylene reduction test (Table 2). Ethylene production was highly significant over the $96 \mathrm{~h}$ incubation (Table 2, jar 6) and was completely inhibited by $\mathrm{NH}_{4}+($ jar 7$)$.

The data presented here show that a pure culture of $T$. ferrooxidans grown on a nitrogenfree medium is able to reduce acetylene to ethylene and incorporate ${ }^{15} \mathrm{~N}_{2}$ into its cell protein. It should, therefore, be considered a true nitrogen fixer. 
I should like to thank D. P. Kelly and R. J. Manchee for their encouragement in this work and to V. M. C. Longyear for his technical help. I am especially grateful to Professor J. R. Postgate for his patience, advice and helpful criticism and to his colleagues R. L. Richards and E. Kavanagh for the ${ }^{15} \mathrm{~N}$ analysis.

\section{REFERENCES}

DILWORTH, M. J. (1966). Acetylene reduction by nitrogen-fixing preparations from Clostridium pasteurianum. Biochimica et biophysica acta 127, 285-294.

Drozd, J. \& Postgate, J. R. (1970). Interference by oxygen in the acetylene-reduction test for aerobic nitrogen-fixing bacteria. Journal of General Microbiology 60, 427-429.

GuAy, R. \& Silver, M. (1975). Thiobacillus acidophilus sp.nov.; isolation and some physiological characteristics. Canadian Journal of Microbiology 21, 281-288.

Leathen, W. W., Kinsel, N. A. \& Braley, S. A. (1956). Ferrobacillus ferrooxidars - a chemosynthetic autotrophic bacterium. Journal of Bacteriology 72, 700-704.
Mackintosh, M. E. (1971). Nitrogen-fixation by Thiobacillus ferrooxidans species. Journal of General Microbiology 66, i-ii.

Postgate, J. R. (1972). The acetylene-reduction test for nitrogen-fixation. Methods in Microbiology 6B, 343-356.

Postgate, J. R., Crumpton, J. E. \& Hunter, J. R. (1961). The measurement of bacterial viabilities by slide culture. Journal of General Microbiology 24, 15-24.

Schöllhorn, R. \& Burris, R. H. (1967). Reduction of azide by the $\mathrm{N}_{2}$-fixing enzyme system. Proceedings of the National Academy of Sciences of the United States of America 57, 1317-1323.

Tsuchiya, H. M., Trivedi, N. C. \& Schuler, M. L. (1974). Microbial mutualism in ore leaching. Biotechnology and Bioengineering XVI, 991-995. 